\title{
Oxidative Toxicity in Diabetes Mellitus: The Role of Nanoparticles and
} Future Therapeutic Strategies

\author{
Mohammad Mahdi Sabahi ${ }^{1,2 \dagger}$, Sara Ami Ahmadi ${ }^{1 \dagger}$, Reza Mahjub ${ }^{3}$, Akram Ranjbar ${ }^{4 *}$ \\ ${ }^{1}$ Student Research Committee, Hamadan University of Medical Sciences, Hamadan, Iran. \\ ${ }^{2}$ Nanomedicine Expert Team (NET), Universal Scientific Education and Research Network (USERN), Tehran, Iran. \\ ${ }^{3}$ Department of Pharmaceutics, School of Pharmacy, Hamadan University of Medical Sciences, Hamadan, Iran \\ ${ }^{4}$ Department of Toxicology and Pharmacology, School of Pharmacy, Hamadan University of Medical Sciences, \\ Hamadan, Iran.
}

Submitted: August 9, 2019

\section{Graphical Abstract}

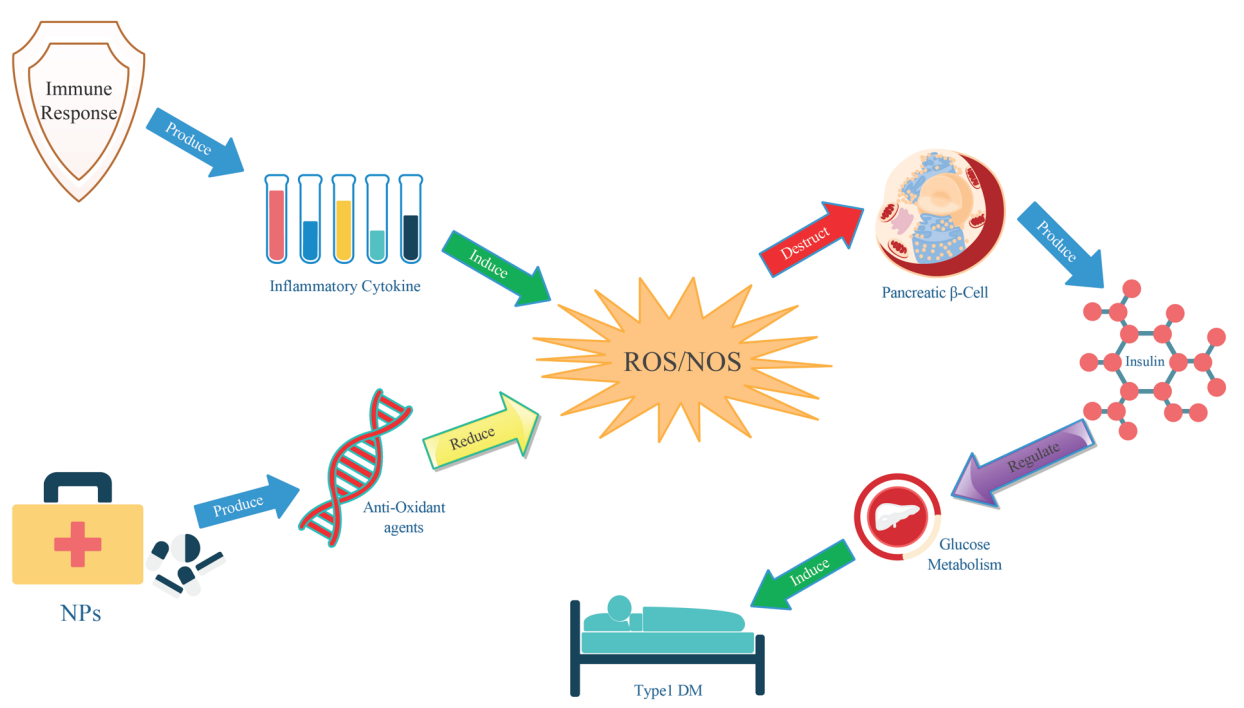

\section{Abstract}

Diabetes mellitus is one of the most common chronic medical conditions in the world. Increasing evidence suggests that chronic hyperglycemia can cause excessive production of free radicals, particularly reactive oxygen species (ROS). Free radicals play important roles in tissue damage in diabetes. The relationship between exposure to nanoparticles (NPs) and diabetes has been reported in many previous studies. Evaluation of the potential benefits and toxic effects of NPs on diabetic disorders is of importance. This review highlights studies on the relationship between NPs and oxidative stress (OS) as well as the possible mechanisms in diabetic animal models and humans.

Keywords:

nanoparticles; diabetes mellitus; oxidative stress

* Corresponding Author: Akram Ranjbar, Associate professor, Hamadan University of Medical Sciences, Hamadan, Iran.:Postcode 6517838678. Email:akranjbar2015@gmail.com ,Tel/Fax: +98 8138380031

${ }^{\dagger}$ These authors contributed equally to this work. 


\section{Purpose and Rationale}

The relationship between exposure to nanoparticles (NPs) and diabetic disorders is of importance. The evaluation of both potential benefits and toxic effects of NPs on diabetic disorders have been reported in a number of previous studies. This review highlights studies on the link between NPs and oxidative stress (OS) in diabetic animal models and humans as well as describes possible mechanisms.

\section{Introduction}

In recent years, nanomedicine is a new aspect of nanotechnology applying NPs for therapeutic purposes, such as drug delivery to various tissues, imaging, and diagnosis of diseases, and treatment (Cho and Borgens, 2012, Chandra et al., 2011, Kreuter, 2005). Metallic and metal oxide nanoparticles (NPs), such as silver, chromium, zinc oxide, and cerium oxide have created enormous challenges in medicine (Hirst et al., 2013). Oxidative stress (OS), an unbalance between the generation of reactive oxygen species (ROS) and antioxidants in the body, is involved in the pathogenesis of many diseases, including diabetes mellitus (DM), neurodegenerative diseases, age-related macular degeneration, and inherited retinal diseases (Zhou et al., 2011). Most of the previous studies focused on type I diabetes in which the level of insulin hormone, the most important hormone involved in regulating glucose, is reduced due to the destruction of the pancreatic $\beta$-cells and their inability to produce insulin. The destruction of pancreatic $\beta$-cells results from an OS-induced immune response and secondary apoptosis (Hosseini et al., 2013). In recent years, antioxidants have been considered as preventative, curative and most importantly, counteracting factors for OS. The main function of antioxidants is converting ROS and reactive nitrogen species (RNS) to non-reactive products (Pellegrini et al., 2003) (Ghadermazi et al., 2018). Since orally delivered antioxidants are destroyed by enzymes and gastric acid and only a small percentage of them are absorbed, they have a small bioavailability with low concentrations in target cells (Souto et al., 2013). Therefore, there is an instant need to develop efficient methods to deliver antioxidants to the target sites. For this purpose, advanced NPs carriers, such as

Prnano.com, https://doi.org/10.33218/prnano2(4).190809.1

The official Journal of CLINAM - ISSN:2639-9431 (online) liposomes, polymeric NPs, solid lipid NPs or selfemulsifying drug delivery systems have been used (Watal et al., 2013). NPs containing antioxidants have been suggested as highperformance therapeutic nanomedicines in attenuating OS with potential applications in treating and preventing DM (Sandhir et al., 2015). The objective of the present mini-review is to summarize existing knowledge on the efficacy of NPs on OS-induced DM.

\section{Oxidative Stress and Diabetes Mellitus}

ROS are produced as a result of the normal cellular metabolism of oxygen. Under the physiological conditions, basal levels of ROS in cells play an important role in cell signaling, defense mechanisms, and homeostasis (Miller et al., 2005). OS occurs as the result of the imbalance between produced endogenous ROS and their cleansing by endogenous antioxidant defense systems (Mitra et al., 2016, Sharifzadeh et al., 2017). Complete destruction of pancreatic $\beta$-cells by autoimmune mechanisms leads to type1 diabetes (T1D). Type 2 diabetes (T2D) is the result of relative degeneration of these cells, caused by multiple issues, such as the failure of peripheral metabolic tissues to respond to insulin action, the liver's inability to control the production of glucose and the demise of islet $\beta$ cells (Halban et al., 2014). Thus, substitute treatments were offered to reduce insulin resistance and improve blood glucose control. NPs were used as a biologically based therapy for this purpose (Neuhouser, 2003, Mehta et al., 2008). $\beta$-cells are invaded by ROS and RNS produced by phagocytic cells. Also, secreted cytokines from immune cells exacerbate oxidative damage of $\beta$-cells. It has been well documented that this is a decisive process in chronic autoimmune disease, type 1 diabetes mellitus (T1DM) (Eizirik et al., 2009). Autoreactive T helper 1(TH1) cells play a crucial role in the autoimmune demolition of $\beta$-cells. The immune cells secrete various types of cytokines that cause ROS/RNS formation in $\beta$-cells (Lortz et al., 2000, Suarez-Pinzon et al., 1996, SuarezPinzon et al., 1997). The pathogenesis of type 2 diabetes is not completely different from that of type 1 diabetes. Prolonged fuel overload induces a state of systemic low-grade inflammation that is linked to cytokine production (Donath et al., 
2003, Feuerer et al., 2009). Cellular secretion capacity and its viability are affected by the OS, and both of these parameters lead to beta-cell damage (Drews et al., 2010).

\section{Nanoparticles Containing Antioxidants}

Different materials, such as metal salts, proteins, polysaccharides, and synthetic polymers are used in the preparation of NPs. Various factors affect the selection of matrix materials, including (a) the size of NPs, (b) the intrinsic properties of the drug, such as its aqueous solubility and stability, (c) surface characteristics, such as charge and permeability, (d) the degree of biodegradability, biocompatibility and toxicity, (e) the desired drug release profile, and (f) the antigenicity of the final product (Mohanraj and Chen, 2006). NPs have the potential to ameliorate disease management due to the ability to overcome multiple biological barriers and create therapeutic effects within the optimal dosage range (Alexis et al., 2008, Ranjbar et al., 2017).

\section{Vanadium NPS}

Vanadium (V) is a trace element widely distributed in nature. It occurs in polyvalences and presents many biological effects (Nielsen, 1995, French and Jones, 1993, Gruzewska et al., 2014). About a century ago, Vanadium was first used to treat DM (Thompson and Orvig, 2006). Vanadium compounds have also been able to treat parasitic diseases, malignant tumors, and bacterial and viral infections (Rehder, 2015).

Non-insulin dependent DM developed through increased insulin resistance and beta-cell dysfunction, which led to a gradual decrease in insulin secretion (Talchai et al., 2009, Tanaka et al., 2011). Vanadium converted cationic type vanadyl into its anionic type vanadate in cells. Vanadate as a potent inhibitor of $\mathrm{Na}^{+}-\mathrm{K}^{+}$ATPase enhances insulin secretion from the pancreatic bcells (Crans et al., 1995) and stimulates GTUT 4 so that glucose transports across the cell increases (Brichard and Henquin, 1995).

\section{Cerium oxide NPS}

Cerium oxide NPs (CeNPs) are ROS scavengers (nanoceria, CeNPs) that mimic the activities of superoxide dismutase (SOD) and (CAT) (Zhou et al., 2011). CeNPs are a good example of oxygen buffers because of their redox behavior. When synthesized as NPs $(3-5 \mathrm{~nm}$ in diameter), they cerium oxide increase oxygen vacuity and can regenerate ROS scavenger activity (Karakoti et al., 2008).

Ameliorate transplantation consequence and graft function by control of OS damage could result in pretreatment with a combination of CeNPs/sodium selenite (Pourkhalili et al., 2012). Although a significant increase in cells viability, secretion of insulin, and adenosine triphosphate/adenosine diphosphate (ATP/ADP) ratio and reduction in ROS can be achieved by the use of sodium selenite, CeNPs and especially the combination of, CeNPs /sodium selenite (Pourkhalili et al., 2012, Moridi et al., 2018, Hosseini et al.).

\section{Chromium NPS}

Chromium $(\mathrm{Cr})$ is an essential trace element needed for the preservation of normal carbohydrate metabolism, as shown in animal and humans studies (Wang and Cefalu, 2010). The role of $\mathrm{Cr}$ as a critical trace element required for normal glucose metabolism looks to be well certified from studies in deprivation conditions (Schwarz and Mertz, 1957).

Moderate diabetic state in rats is a result of partial dietary deficiency of $\mathrm{Cr}$ represented by an increase in fasting serum glucose and glycosuria and low tolerance to glucose, which could be returned by supplemental Cr (Schwarz and Mertz, 1957). Some studies refer to conditions of dietary deficiency of $\mathrm{Cr}$, including the diagnosis of $\mathrm{Cr}$ deficiency with the use of total parenteral nutrition in humans (Schroeder, 1966, Freund et al., 1979, Anderson, 2000).

$\mathrm{Cr}$ increases the number of insulin receptors and the sensitivity of $\beta$-cells even though enhance insulin binding. Some studies showed the isolation of a protein termed chromodulin that linked Cr to receptor signaling (Anderson, 2000, Anderson, 1997, Vincent, 2000b, Vincent, 1999, Vincent, 2000a).

\section{Zinc oxide NPS}

One of the major causes of pancreas $\beta$ cell's disability in synthesizing and secreting insulin to the blood is Zn deficiency (Meyer and Spence, 2009). According to the antioxidant role of zinc, zinc deficiency can result in aggravating OS interceding complications of diabetes (Hussein et 
al., 2014). Afifi et al. showed the antioxidant ability of ZnNPs in diabetic rat brain. Diabetic rats treated with zinc oxide showed an increase in the activity and mRNA expression levels of SOD, CAT, glutathione reductase GRd, glutathione peroxidase (GPx), and GSH and decreased malondialdehyde (MDA) levels in the brain (Afifi and Abdelazim, 2015). The antioxidant ability of ZnNPs may explain the potent antidiabetic effects of ZnNPs. ZnNPs resulted in significantly increased levels of insulin in serum, reduced levels of blood glucose, and activation of glucose oxidation, inhibiting hyperglycemia in diabetic rats (Alkaladi et al., 2014). This decreases the generation of advanced glycation end products such as SOD (Warboys et al., 2009). Only a few studies investigate the effects of ZnNPs on insulin levels or secretion. Reports show that ZnNPs could increase insulin secretion from rat isolated pancreatic islets stimulated by glucose (Richards-Williams et al., 2008).

\section{Curcumin NPS}

Curcumin is an active principle present in the yellow spice turmeric. Various pharmacological benefits such as antimicrobial, antioxidant, antiinflammatory, and anticarcinogenic activities have been reported for it (Grama et al., 2013). Encapsulating curcumin in the NPs has been envisaged as a new delivery method to treat a spectrum of diseases (Rabanel et al., 2015). Rabanel et al. showed that encapsulated curcumin is an effective method to protect cells against hydrogen peroxide OS (Rabanel et al., 2015). Grama et al. reported considerable useful effects of chronic nanocurcumin therapy for the delay in cataract formation as a consequence of diabetes in animals. The delay in the progression of diabetic cataract by nanocurcumin was defined by its ability to modify biochemical mechanisms and pathways that are connected to the progression of cataracts, such as protein precipitation, protein glycation, OS, crystallin dispensation, and polyol pathway. The therapeutic function of nanocurcumin on these biochemical pathways is distinguished in comparison to curcumin.

\section{Selenium NPS}

Selenium (Se) is a necessary element for humans and can increase the activities of the selenoenzymes and antioxidant enzymes, such as GPx. In vivo studies showed that $\mathrm{Se}$ is a defense tissue against free radicals. Se interaction with GPx is notably critical and well-understood because GPx is recognized to have an important function in scavenging different peroxides and support membrane lipids and macromolecules from oxidative damage (Klotz et al., 2003, Valko et al., 2006). Saleh Al-Quraishy et al. found that the stimulation of glycogen synthase activity in rats treated with SeNPs is due to increased glycogen contents in the liver and kidney. SeNPs have strong therapeutic effects by restoring severe biochemical and histochemical changes in the liver and kidney induced by DM. This protection may be provided by imitation of insulin and/or because of its free radical scavenging effect (Al-Quraishy et al., 2015).

\section{Nanoparticles Containing Insulin}

In recent years, the prevalence of diabetes has grown dramatically worldwide. The most common treatment for T1DM is the daily injection of insulin. At this point, researchers are working to develop insulin delivery systems, with special attention to nanoparticulate delivery systems through oral and lung pathways. The new generation of drugs for T1DM may assist in enhancing the quality of life of diabetic people who inject insulin. In this review, we have summarized a new generation of NPs containing insulin. These nanocarriers include chitosaninsulin NPs (Shashavari et. al., 2014) LGAinsulin NPs, dextran-insulin NPs, polyalkylcyanoacrylated-insulin NPs, and solid lipid-insulin NPs. Modulation of these insulin nanocarriers may lead to successful oral or pulmonary insulin nanoformulations formulations in the future clinical settings. Therefore, applications and limitations of these NPs in delivering insulin to the target cells have been thoroughly discussed.

Nanotechnology is a tool to reduce the limitations of carriers and various strategies that use natural polymers such as chitosan, alginate, poly- $\gamma$-glutamic acid and their derivatives, or synthetic polymers such as poly(lactide-coglycolide), pluronic/poly(lactic acid), poly( $\epsilon-$ caprolactone) and L-lysine/L-leucine-based poly(ester amide) have been used for development of insulin nanoparticles. 


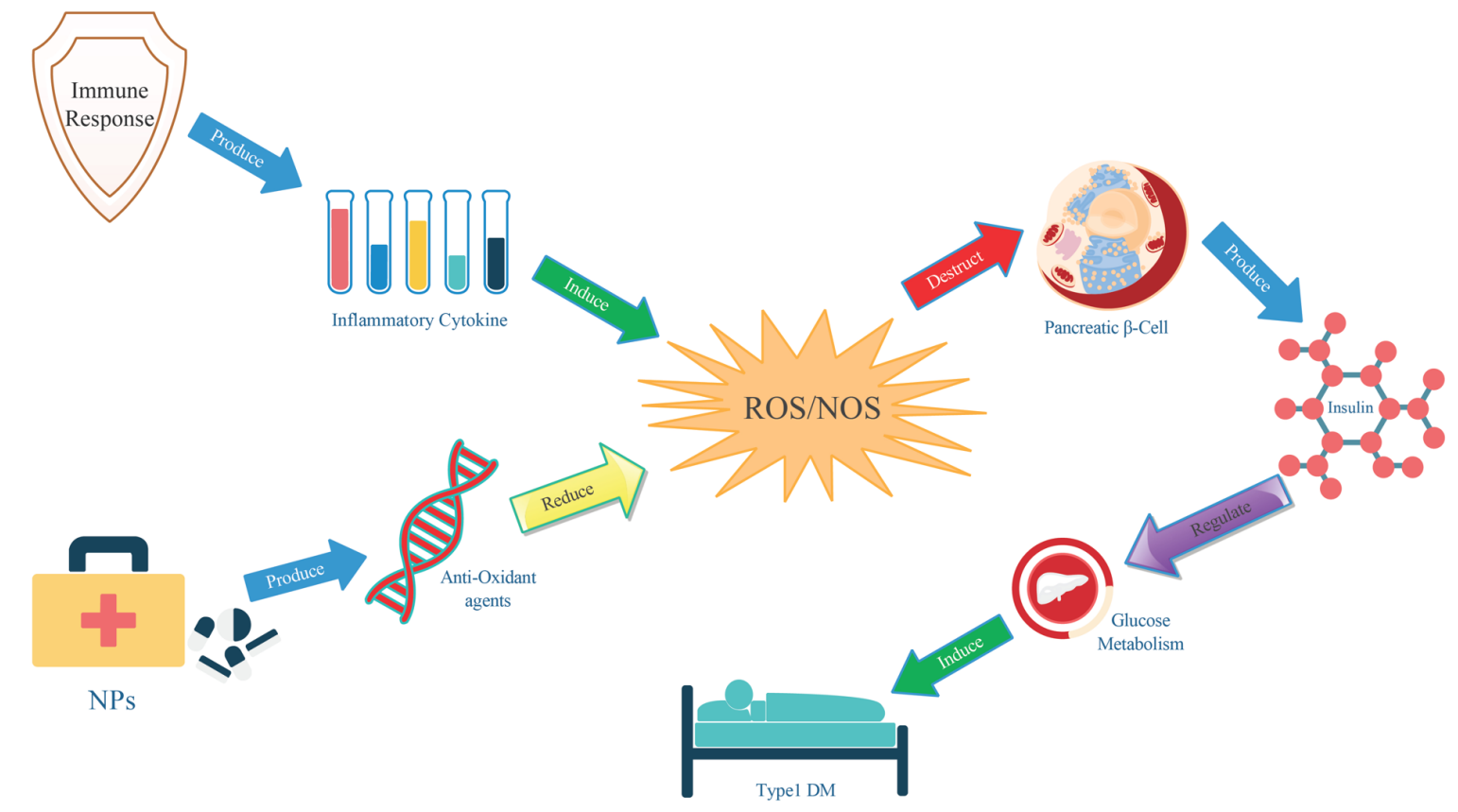

Figure1. Schematic representation of nanoparticles as a vehicle for therapeutics and their innate antioxidant properties for the effective treatment of type 1 diabetes mellitus (DM).

An interesting approach has recently been put forward that combines nanotechnology with pharmaceutical formulation technology. In this approach, a pellet host insulin-loaded polyethylenimine NPs is a pretty good example (Salvioni et al., 2016). The pellet is formed by three-layer release technology platform, which merges an outer gastro-resistant layer with a flexible film of a neutral polymethacrylate Eudragit@NE and sodium starch glycolate Explotab ${ }^{\circledR}$, applied to a hydroxypropyl methylcellulose coating (Palugan et al., 2015, Maroni et al., 2013, Del Curto et al., 2014). The only combination can mediate the colonic release of insulin and obtaining a long-lasting hypoglycemic effect, is the three-layer technology with poly ethylene imine nanoformulation (Salvioni et al., 2016). Many studies showed the crucial role of the combination of three-layer technology and NPmediated insulin delivery and pave a new way to obtain therapeutic efficacy for oral insulin.

By using a protective $\mathrm{pH}$-sensitive coating, the insulin degradation in the stomach is prevented and its absorption in the intestine is facilitated. While mucoadhesive materials increase the rate of insulin absorption from the paracellular pathway by reducing intestinal movements, some studies have been performed to develop targeted NPs against enterocytes, mucus layer and M cells, through the functionalization with lectin. However, the oral delivery of insulin is still an unresolved challenge (Luo et al., 2016).

In the study performed by Cui et al., (2007), insulin-containing nanoparticles prepared from PLGA (PNP) and PLGA-Hp55 (PHNP) were studied as an alternative approach for deduction of glucose level. It was demonstrated that the relative bioavailability of PNP and PHNP compared with subcutaneous injection $(1 \mathrm{IU} / \mathrm{kg}$ ) in diabetic rats observed was $3.68 \pm 0.29$ and $6.27 \pm 0.42 \%$, respectively. It was seen that, after 12 hours of administration, the plasma glucose level was reduced to $23.85 \%$ from the initial level, and this conditioned was maintained for 24 hours. Sodium oleate is an anionic surfactant which forms an ionic complex with positively charged insulin at suitable $\mathrm{pH}$ and improves the 
apparent liposolubility of insulin. These approaches can be provided in a single oral dose which could eliminate the need for repeated insulin doses for 24 hours. In a study, folate (FA) coupled PEG-PLGA nanoparticles were used to encapsulate insulin by the solvent evaporation method and showed that once-daily administration would be sufficient to control diabetes for at least 24 hours (Jain et al., 2012).

In one study, nanoparticles made of lauryl succinyl chitosan were developed, and it was found that the presence of succinyl carboxyl groups had inhibitory effects on in vitro release of insulin at pH 1.2 (Rekha and Sharma, 2009). Such nanoparticles, when administered to diabetic rats, were also able to reduce blood glucose levels for approximately 6 hours. Alginate has also been applied for oral insulin delivery. Insulinencapsulated into alginate nanoparticles reduced the basal serum glucose levels by $40 \%$ after oral administration to diabetic rats (Sarmento et al., 2007). In another study, insulin complexed with cationic $\beta$-cyclodextrin polymers in alginate/chitosan nanoparticles showed the ability of cationic $\beta$-cyclodextrin polymers to protect insulin from degradation under simulated gastrointestinal conditions and to have controlled-release properties (Reis et al., 2007). Nanoparticles formulated with polylactic acid, ethylene oxide, and propylene oxide triblock demonstrated potential capacity in delivering insulin orally, decreasing blood glucose concentration in diabetic animals and maintaining a significant hypoglycemic effect for 24 hours (Xiong et al., 2007). The nanoparticles were administered to diabetic rats and reduced the plasma glucose levels to $40 \%$ of the basal values, with a sustained hypoglycemic effect over 24 hours. Furthermore, a dose of $50 \mathrm{IU} / \mathrm{kg}$ showed an oral bioavailability (13\%) three-fold higher than orally administered insulin.

Pan et al. (Pan et al., 2002) prepared insulinloaded chitosan nanoparticles by ionotropic gelation method and although they showed the hypoglycemic effect was prolonged for more than 15 hours, the bioavailability of the NPs was only $14.9 \%$ when compared to a subcutaneous injection of insulin. Following this study, another group performed similar studies with insulinencapsulated chitosan nanoparticles and evaluated their pharmacological impact in rats (Ma et al., 2005) Since it was found from a previous study that the $\mathrm{pH}$ of the formulation had a significant impact on the association efficiency and in vitro release of insulin from CS-NPs (Ma et al., 2002), the researchers altered the $\mathrm{pH}$ of the formulation to $\mathrm{pH}$ of 5.3 and 6.1. However, the results obtained were similar to the previous study, and the formulation was unable to maintain the hypoglycemic effect for more than 11 hours. Insulin-loaded chitosan-alginate nanoparticles at a dose of 25,50 , or $100 \mathrm{IU} / \mathrm{kg}$ were orally administered to the diabetic mice (Sarmento et al., 2007), it showed a significant reduction in plasma glucose level ( 8 to 14 hours after administration) when compared to the empty NPs. A dose-dependent effect was observed; however, no significant difference was seen between the dose of 50 and $100 \mathrm{IU} / \mathrm{kg}$ probably due to saturation of the insulin absorption sites. More importantly, when empty NPs were administered in insulin solution (50 IU/ $\mathrm{kg}$ ), only a minor hypoglycemic effect was observed between 2 and 8 hours after administration. Thus, the results emphasized on nanoencapsulation of insulin into the alginate-chitosan nanoparticles, since this protected the protein from enzymatic degradation. Secondly, the results indicated a prolonged hypoglycemic effect up to 24 hours when compared to previously formulated insulinencapsulated CS-NPs where the effect was only up to 12 hours or less (Papadimitriou et al., 2008). A summary of the studies conducted on the effects of nanoparticles on DM is presented in Table 1. 
Table 1. Summary of Studies Conducted on the Effect of Nanoparticles on Diabetes Mellitus

\begin{tabular}{|c|c|c|c|c|c|}
\hline Row & Authors & Year of study & Location & Nanoparticle & Efficacy of NPs on DM \\
\hline 1 & Crans et al. & 1995 & $\begin{array}{l}\text { Colorado State } \\
\text { University }\end{array}$ & Vanadium & $\begin{array}{l}\text { increases the release of insulin } \\
\text { from the pancreatic } \beta \text {-cells }\end{array}$ \\
\hline 2 & Pourkhalili et al. & 2012 & $\begin{array}{l}\text { Pharmaceutical } \\
\text { Sciences Research } \\
\text { Center, Tehran, Iran }\end{array}$ & Cerium oxide & $\begin{array}{l}\text { increase in cells viability, } \\
\text { secretion of insulin, and } \\
\text { ATP/ADP ratio and reduction in } \\
\text { ROS }\end{array}$ \\
\hline 3 & Moridi et al. & 2018 & $\begin{array}{l}\text { Hamadan University } \\
\text { of Medical Sciences }\end{array}$ & Cerium oxide & increases secretion of insulin \\
\hline 4 & Anderson & 2000 & $\begin{array}{l}\text { Beltsville Human } \\
\text { Nutrition Research }\end{array}$ & Chromium & $\begin{array}{l}\text { increases the number of insulin } \\
\text { receptors and the sensitivity of } \beta \text { - } \\
\text { cells }\end{array}$ \\
\hline 5 & Vincent & 2000 & $\begin{array}{l}\text { The University of } \\
\text { Alabama }\end{array}$ & Chromium & enhanced insulin binding \\
\hline$\overline{6}$ & Afifi et al. & 2015 & University of Jeddah & Zinc oxide & $\begin{array}{l}\text { increased of SOD, CAT, GRD, } \\
\text { GPx and GSH mRNA expression } \\
\text { levels }\end{array}$ \\
\hline 7 & Alkaladi et al. & 2014 & $\begin{array}{l}\text { King Abdulaziz } \\
\text { University }\end{array}$ & Zinc oxide & $\begin{array}{l}\text { increased levels of insulin in } \\
\text { serum and reduced levels of } \\
\text { blood glucose }\end{array}$ \\
\hline 8 & $\begin{array}{l}\text { Richards-Williams et } \\
\text { al. }\end{array}$ & 2008 & $\begin{array}{l}\text { University of } \\
\text { Alabama at } \\
\text { Birmingham }\end{array}$ & Zinc oxide & $\begin{array}{l}\text { increase the insulin secretion } \\
\text { from rat isolated pancreatic islets }\end{array}$ \\
\hline 9 & Grama et al. & 2013 & $\begin{array}{l}\text { University of } \\
\text { Strathclyde }\end{array}$ & Curcumin & $\begin{array}{l}\text { Causes significant delay in } \\
\text { progression of diabetic cataract }\end{array}$ \\
\hline 10 & Al-Quraishy et al. & 2015 & $\begin{array}{l}\text { King Saud } \\
\text { University }\end{array}$ & Selenium & $\begin{array}{l}\text { Enhanced glycogen contents in } \\
\text { the liver and kidney through the } \\
\text { stimulation of glycogen synthase } \\
\text { activity }\end{array}$ \\
\hline
\end{tabular}

$\mathrm{ATP} / \mathrm{ADP}=$ adenosine triphosphate/adenosine diphosphate; $\mathrm{CAT}=$ catalase; $\mathrm{DM}=$ diabetes mellitus; $\mathrm{GPx}=$ glutathione peroxidase; GRd glutathione reductase; GSH mRNA = glutathione messenger ribonucleic acid; ROS = reactive oxygen species; $\mathrm{SOD}=$ superoxide dismutase

\section{Conclusion}

Nanotechnology has provided a promising platform for engineering insulin carriers. The present brief review aims to analyze the effects of nanoparticles on oxidative stress in diabetes mellitus. Elevated levels of ROS are related to DM in the hyperglycemic pathways. Some NPs are antioxidants and may improve DM disorders. However, some outstanding problems remain in diabetes care, such as the need for improved glucose sensing, oral insulin formulations, and transplantation of islets with enhanced survival are likely to have nanomedicine solutions and research is already very active in these areas. Many studies have contributed to the ability of colloidal NPs to increase insulin absorption in the colon; however, these drugs are limited due to the inability of NPs be safely transported through the intestine and stomach. There have been many new investigations and discoveries of potential NPs to oral administration of insulin, and these formulations are continuously being improved for OS reduction, the future of oral insulin looks promising. However, very few studies have focused on the effects of NPs on diabetes, and further research is needed to clarify the mechanism of these NPs.

Funding: No funding was received for this research. 


\section{Compliance with Ethical Standards}

This study is a review article which is not related to human and animal subjects. All procedures performed in these studies involving data gathering, avoiding of plagiarism were in accordance with the ethical standards of the national research committee (Hamadan university of medical sciences) and with the 1964 Helsinki declaration and its later amendments or comparable ethical standards.

Conflict of Interests

The authors declare no conflicts of interest. For signed statements, please contact the journal office: editor@precisionnanomedicine.com

Quote this article as: Sabahi MM, Ahmadi SA, Mahjub R, Ranjbar A, Oxidative Toxicity in Diabetes Mellitus: The Role of Nanoparticles and Future Therapeutic Strategies, Precis. Nanomed. 2019;2(4):382392, https://doi.org/10.33218/prnano2(4)190809.1

\section{References:}

AFIFI, M. \& ABDELAZIM, A. M. 2015. Ameliorative effect of zinc oxide and silver nanoparticles on antioxidant system in the brain of diabetic rats. Asian Pacific Journal of Tropical Biomedicine, 5, 874-877.

AL-QURAISHY, S., DKHIL, M. A. \& ABDEL MONEIM, A. E. 2015. Anti-hyperglycemic activity of selenium nanoparticles in streptozotocin-induced diabetic rats. Int J Nanomedicine, 10, 6741-56.

ALEXIS, F., PRIDGEN, E., MOLNAR, L. K. \& FAROKHZAD, O. C. 2008. Factors affecting the clearance and biodistribution of polymeric nanoparticles. Molecular pharmaceutics, 5, 505-515.

ALKALADI, A., ABDELAZIM, A. M. \& AFIFI, M. 2014. Antidiabetic activity of zinc oxide and silver nanoparticles on streptozotocin-induced diabetic rats. International journal of molecular sciences, 15, 20152023.

ANDERSON, R. A. 1997. Nutritional factors influencing the glucose/insulin system: chromium. Journal of the American College of Nutrition, 16, 404-410.

ANDERSON, R. A. 2000. Chromium in the prevention and control of diabetes. Diabetes Metab, 26, $22-7$.

BRICHARD, S. M. \& HENQUIN, J.-C. 1995. The role of vanadium in the management of diabetes. Trends in Pharmacological Sciences, 16, 265-270.

CHANDRA, S., BARICK, K. \& BAHADUR, D. 2011. Oxide and hybrid nanostructures for therapeutic applications. Advanced Drug Delivery Reviews, 63, 1267-1281.

CHO, Y. \& BORGENS, R. B. 2012. Polymer and nano-technology applications for repair and reconstruction of the central nervous system. Experimental neurology, 233, 126-144.

CRANS, D. C., MAHROOF-TAHIR, M. \& KERAMIDAS, A. D. 1995. Vanadium chemistry and biochemistry of relevance for use of vanadium compounds as antidiabetic agents. Vanadium Compounds: Biochemical and Therapeutic Applications. Springer.

CUI, F. D., TAO, A. J., CUN, D. M., ZHANG, L. Q. \& SHI, K. 2007. Preparation of insulin loaded PLGAHp55 nanoparticles for oral delivery. Journal of pharmaceutical sciences, 96, 421-427.

DEL CURTO, M. D., PALUGAN, L., FOPPOLI, A., ZEMA, L., GAZZANIGA, A. \& MARONI, A. 2014. Erodible Time-Dependent Colon Delivery Systems with Improved Efficiency in Delaying the Onset of Drug Release. Journal of pharmaceutical sciences, 103, 3585-3593.

DONATH, M. Y., STØRLING, J., MAEDLER, K. \& MANDRUP-POULSEN, T. 2003. Inflammatory mediators and islet $\beta$-cell failure: a link between type 1 and type 2 diabetes. Journal of molecular medicine, 81 , 455-470.

DREWS, G., KRIPPEIT-DREWS, P. \& DÜFER, M. 2010. Oxidative stress and beta-cell dysfunction. Pflügers Archiv-European Journal of Physiology, 460, 703-718.

EIZIRIK, D. L., COLLI, M. L. \& ORTIS, F. 2009. The role of inflammation in insulitis and $\beta$-cell loss in type 1 diabetes. Nature Reviews Endocrinology, 5, 219-226.

FEUERER, M., HERRERO, L., CIPOLlETTA, D., NAAZ, A., WONG, J., NAYER, A., LEE, J., GOLDFINE, A. B., BENOIST, C. \& SHOELSON, S. 2009. Lean, but not obese, fat is enriched for a unique population of regulatory T cells that affect metabolic parameters. Nature medicine, 15, 930-939. 
FRENCH, R. J. \& JONES, P. J. 1993. Role of vanadium in nutrition: metabolism, essentiality and dietary considerations. Life sciences, 52, 339-346.

FREUND, H., ATAMIAN, S. \& FISCHER, J. E. 1979. Chromium deficiency during total parenteral nutrition. Jama, 241, 496-498.

GHADERMAZI, R., KHOSHJOU, F., HOSSINI ZIJOUD, S. M., BEHROOJ, H., KHEIRIPOUR, N., GANJI, M., MORIDI, H., MOHAMMADI, M. \& RANJBAR, A. 2018. Hepatoprotective effect of tempol on oxidative toxic stress in STZ-induced diabetic rats. Toxin reviews, 37, 82-86.

GRAMA, C. N., SURYANARAYANA, P., PATIL, M. A., RAGHU, G., BALAKRISHNA, N., KUMAR, M. R. \& REDDY, G. B. 2013. Efficacy of biodegradable curcumin nanoparticles in delaying cataract in diabetic rat model. PloS one, 8, e78217.

GRUZEWSKA, K., MICHNO, A., PAWELCZYK, T. \& BIELARCZYK, H. 2014. Essentiality and toxicity of vanadium supplements in health and pathology. J Physiol Pharmacol, 65, 603-611.

HALBAN, P. A., POLONSKY, K. S., BOWDEN, D. W., HAWKINS, M. A., LING, C., MATHER, K. J., POWERS, A. C., RHODES, C. J., SUSSEL, L. \& WEIR, G. C. 2014. $\beta$-cell failure in type 2 diabetes: postulated mechanisms and prospects for prevention and treatment. Diabetes care, 37, 1751-1758.

HIRST, S. M., KARAKOTI, A., SINGH, S., SELF, W., TYLER, R., SEAL, S. \& REILLY, C. M. 2013. Biodistribution and in vivo antioxidant effects of cerium oxide nanoparticles in mice. Environmental toxicology, 28, 107-118.

HOSSEINI, A., BAEERI, M., RAHIMIFARD, M., NAVAEI-NIGJEH, M., MOHAMMADIRAD, A., POURKHALILI, N., HASSANI, S., KAMALI, M. \& ABDOLLAHI, M. 2013. Antiapoptotic effects of cerium oxide and yttrium oxide nanoparticles in isolated rat pancreatic islets. Human \& experimental toxicology, 32, 544-553.

HOSSEINI, S. A., SAIDIJAM, M., KARIMI, J., AZARI, R. Y., HOSSEINI, V. \& RANJBAR, A. Cerium Oxide Nanoparticle Effects on Paraoxonase-1 Activity and Oxidative Toxic Stress Induced by Malathion: A Potential Antioxidant Compound, Yes or No? Indian Journal of Clinical Biochemistry, 1-6.

HUSSEIN, S. A., EL-SENOSI, Y. A., EL-DAWY, K. \& BAZ, H. A. 2014. Protective effect of zinc oxide nanoparticles on oxidative stress in experimental-induced diabetes in rats. Benha Veterinary Medical Journal, 27, 405-414.

JAIN, S., RATHI, V. V., JAIN, A. K., DAS, M. \& GODUGU, C. 2012. Folate-decorated PLGA nanoparticles as a rationally designed vehicle for the oral delivery of insulin. Nanomedicine, 7, 1311-1337.

KARAKOTI, A., MONTEIRO-RIVIERE, N., AGGARWAL, R., DAVIS, J., NARAYAN, R. J., SELF, W., MCGINNIS, J. \& SEAL, S. 2008. Nanoceria as antioxidant: synthesis and biomedical applications. JOM Journal of the Minerals, Metals and Materials Society, 60, 33-37.

KLOTZ, L.-O., KRÖNCKE, K.-D., BUCHCZYK, D. P. \& SIES, H. 2003. Role of copper, zinc, selenium and tellurium in the cellular defense against oxidative and nitrosative stress. The Journal of nutrition, 133, 1448S$1451 \mathrm{~S}$.

KREUTER, J. Application of nanoparticles for the delivery of drugs to the brain. International Congress Series, 2005. Elsevier, 85-94.

LORTZ, S., TIEDGE, M., NACHTWEY, T., KARLSEN, A. E., NERUP, J. \& LENZEN, S. 2000. Protection of insulin-producing RINm5F cells against cytokine-mediated toxicity through overexpression of antioxidant enzymes. Diabetes, 49, 1123-1130.

LUO, Y. Y., XIONG, X. Y., TIAN, Y., LI, Z. L., GONG, Y. C. \& LI, Y. P. 2016. A review of biodegradable polymeric systems for oral insulin delivery. Drug delivery, 23, 1882-1891.

MA, Z., LIM, T. M. \& LIM, L.-Y. 2005. Pharmacological activity of peroral chitosan-insulin nanoparticles in diabetic rats. International journal of pharmaceutics, 293, 271-280.

MA, Z., YEOH, H. H. \& LIM, L. Y. 2002. Formulation pH modulates the interaction of insulin with chitosan nanoparticles. Journal of pharmaceutical sciences, 91, 1396-1404.

MARONI, A., DEL CURTO, M. D., CEREA, M., ZEMA, L., FOPPOLI, A. \& GAZZANIGA, A. 2013. Polymeric coatings for a multiple-unit pulsatile delivery system: preliminary study on free and applied films. International journal of pharmaceutics, 440, 256-263. 
MEHTA, D. H., GARDINER, P. M., PHILLIPS, R. S. \& MCCARTHY, E. P. 2008. Herbal and dietary supplement disclosure to health care providers by individuals with chronic conditions. The Journal of Alternative and Complementary Medicine, 14, 1263-1269.

MEYER, J. A. \& SPENCE, D. M. 2009. A perspective on the role of metals in diabetes: past findings and possible future directions. Metallomics, 1, 32-41.

MILlER, E. W., ALBERS, A. E., CHANG, C. J., PRALLE, A. \& ISACOFF, E. Y. 2005. Boronate-based fluorescent probes for imaging cellular hydrogen peroxide. Journal of the American chemical society, 127, 16652.

MITRA, R. N., CONLEY, S. M. \& NAASH, M. I. 2016. Therapeutic approach of nanotechnology for oxidative stress induced ocular neurodegenerative diseases. Retinal Degenerative Diseases. Springer.

MOHANRAJ, V. \& CHEN, Y. 2006. Nanoparticles-a review. Tropical Journal of Pharmaceutical Research, 5, 561-573.

MORIDI, H., HOSSEINI, S. A., SHATERI, H., KHEIRIPOUR, N., KAKI, A., HATAMI, M. \& RANJBAR, A. 2018. Protective effect of cerium oxide nanoparticle on sperm quality and oxidative damage in malathioninduced testicular toxicity in rats: An experimental study. International Journal of Reproductive Biomedicine, $16,261$.

NEUHOUSER, M. L. 2003. Dietary supplement use by American women: challenges in assessing patterns of use, motives and costs. The Journal of nutrition, 133, 1992S-1996S.

NIELSEN, F. 1995. Vanadium in mammalian physiology and nutrition. Metal ions in biological systems, 31, 543.

PALUGAN, L., CEREA, M., ZEMA, L., GAZZANIGA, A. \& MARONI, A. 2015. Coated pellets for oral colon delivery. Journal of Drug Delivery Science and Technology, 25, 1-15.

PAN, Y., LI, Y.-J., ZHAO, H.-Y., ZHENG, J.-M., XU, H., WEI, G. \& HAO, J.-S. 2002. Bioadhesive polysaccharide in protein delivery system: chitosan nanoparticles improve the intestinal absorption of insulin in vivo. International journal of pharmaceutics, 249, 139-147.

PAPADIMITRIOU, S., BIKIARIS, D., AVGOUSTAKIS, K., KARAVAS, E. \& GEORGARAKIS, M. 2008. Chitosan nanoparticles loaded with dorzolamide and pramipexole. Carbohydrate Polymers, 73, 44-54.

PELlEGRINI, N., SERAFINI, M., COLOMBI, B., DEL RIO, D., SAlVATORE, S., BIANCHI, M. \& BRIGHENTI, F. 2003. Total antioxidant capacity of plant foods, beverages and oils consumed in Italy assessed by three different in vitro assays. The Journal of nutrition, 133, 2812-2819.

POURKHALILI, N., HOSSEINI, A., NILI-AHMADABADI, A., RAHIMIFARD, M., NAVAEI-NIGJEH, M., HASSANI, S., BAEERI, M. \& ABDOLLAHI, M. 2012. Improvement of isolated rat pancreatic islets function by combination of cerium oxide nanoparticles/sodium selenite through reduction of oxidative stress. Toxicology mechanisms and methods, 22, 476-482.

RABANEL, J.-M., FAIVRE, J., PAKA, G. D., RAMASSAMY, C., HILDGEN, P. \& BANQUY, X. 2015. Effect of polymer architecture on curcumin encapsulation and release from PEGylated polymer nanoparticles: Toward a drug delivery nano-platform to the CNS. European Journal of Pharmaceutics and Biopharmaceutics, 96, 409-420.

RANJBAR, A., FIROZIAN, F., SOLEIMANI ASL, S., GHASEMI, H., TAHERI AZANDARIANI, M., LARKI, A., KHEIRIPOUR, N., HOSSEINI, A. \& NASERABADI, A. 2017. Nitrosative DNA damage after sub-chronic exposure to silver nanoparticle induces stress nephrotoxicity in rat kidney. Toxin Reviews, 1-7.

REHDER, D. 2015. The role of vanadium in biology. Metallomics, 7, 730-742.

REIS, C. P., RIBEIRO, A. J., HOUNG, S., VEIGA, F. \& NEUFELD, R. J. 2007. Nanoparticulate delivery system for insulin: design, characterization and in vitro/in vivo bioactivity. european journal of pharmaceutical sciences, 30, 392-397.

REKHA, M. \& SHARMA, C. P. 2009. Synthesis and evaluation of lauryl succinyl chitosan particles towards oral insulin delivery and absorption. Journal of Controlled Release, 135, 144-151.

RICHARDS-WILLIAMS, C., CONTRERAS, J. L., BERECEK, K. H. \& SCHWIEBERT, E. M. 2008. Extracellular ATP and zinc are co-secreted with insulin and activate multiple P2X purinergic receptor channels expressed by islet beta-cells to potentiate insulin secretion. Purinergic signalling, 4, 393. 
SALVIONI, L., FIANDRA, L., DEL CURTO, M. D., MAZZUCCHELLI, S., ALLEVI, R., TRUFFI, M., SORRENTINO, L., SANTINI, B., CEREA, M. \& PALUGAN, L. 2016. Oral delivery of insulin via polyethylene imine-based nanoparticles for colonic release allows glycemic control in diabetic rats. Pharmacological research, 110, 122-130.

SANDHIR, R., YADAV, A., SUNKARIA, A. \& SINGHAL, N. 2015. Nano-antioxidants: an emerging strategy for intervention against neurodegenerative conditions. Neurochemistry international, 89, 209-226.

SARMENTO, B., RIBEIRO, A., VEIGA, F., SAMPAIO, P., NEUFELD, R. \& FERREIRA, D. 2007. Alginate/chitosan nanoparticles are effective for oral insulin delivery. Pharmaceutical research, 24, 2198-2206.

SCHROEDER, H. A. 1966. Chromium deficiency in rats: a syndrome simulating diabetes mellitus with retarded growth. Journal of Nutrition, 88, 439-445.

SCHWARZ, K. \& MERTZ, W. 1957. A glucose tolerance factor and its differentiation from factor 3. Archives of biochemistry and biophysics, 72, 515-518.

SHARIFZADEH, M., RANJBAR, A., HOSSEINI, A. \& KHANAVI, M. 2017. The effect of green tea extract on oxidative stress and spatial learning in Streptozotocin-diabetic rats. Iranian journal of pharmaceutical research: IJPR, 16, 201.

SOUTO, E. B., SEVERINO, P., BASSO, R. \& SANTANA, M. H. A. 2013. Encapsulation of antioxidants in gastrointestinal-resistant nanoparticulate carriers. Oxidative Stress and Nanotechnology: Methods and Protocols, 37-46.

SUAREZ-PINZON, W. L., STRYNADKA, K. \& RABINOVITCH, A. 1996. Destruction of rat pancreatic islet beta-cells by cytokines involves the production of cytotoxic aldehydes. Endocrinology, 137, 5290-5296.

SUAREZ-PINZON, W. L., SZABÓ, C. \& RABINOVITCH, A. 1997. Development of autoimmune diabetes in NOD mice is associated with the formation of peroxynitrite in pancreatic islet $\beta$-cells. Diabetes, 46, 907-911.

TALCHAI, C., LIN, H., KITAMURA, T. \& ACCILI, D. 2009. Genetic and biochemical pathways of $\beta$-cell failure in type 2 diabetes. Diabetes, Obesity and Metabolism, 11, 38-45.

TANAKA, H., SHIMAYA, A., KISO, T., KURAMOCHI, T., SHIMOKAWA, T. \& SHIBASAKI, M. 2011. Enhanced insulin secretion and sensitization in diabetic mice on chronic treatment with a transient receptor potential vanilloid 1 antagonist. Life sciences, 88, 559-563.

THOMPSON, K. H. \& ORVIG, C. 2006. Vanadium in diabetes: 100 years from Phase 0 to Phase I. Journal of Inorganic Biochemistry, 100, 1925-1935.

VALKO, M., RHODES, C., MONCOL, J., IZAKOVIC, M. \& MAZUR, M. 2006. Free radicals, metals and antioxidants in oxidative stress-induced cancer. Chemico-biological interactions, 160, 1-40.

VINCENT, J. B. 1999. Mechanisms of chromium action: low-molecular-weight chromium-binding substance. Journal of the American College of Nutrition, 18, 6-12.

VINCENT, J. B. 2000a. The biochemistry of chromium. The Journal of nutrition, 130, 715-718.

VINCENT, J. B. 2000b. Elucidating a biological role for chromium at a molecular level. Accounts of chemical research, 33, 503-510.

WANG, Z. Q. \& CEFALU, W. T. 2010. Current concepts about chromium supplementation in type 2 diabetes and insulin resistance. Current diabetes reports, 10, 145-151.

WARBOYS, C. M., TOH, H.-B. \& FRASER, P. A. 2009. Role of NADPH oxidase in retinal microvascular permeability increase by RAGE activation. Investigative ophthalmology \& visual science, 50, 1319-1328.

WATAL, G., WATAL, A., RAI, P. K., RAI, D. K., SHARMA, G. \& SHARMA, B. 2013. Biomedical applications of nano-antioxidant. Oxidative Stress and Nanotechnology: Methods and Protocols, 147-151.

XIONG, X. Y., LI, Y. P., LI, Z. L., ZHOU, C. L., TAM, K. C., LIU, Z. Y. \& XIE, G. X. 2007. Vesicles from Pluronic/poly (lactic acid) block copolymers as new carriers for oral insulin delivery. Journal of Controlled Release, 120, 11-17.

ZHOU, X., WONG, L. L., KARAKOTI, A. S., SEAL, S. \& MCGINNIS, J. F. 2011. Nanoceria inhibit the development and promote the regression of pathologic retinal neovascularization in the Vldlr knockout mouse. PloS one, 6, e16733. 